\title{
A Critical Review of Bilingual Education in the United States: From Basements and Pride to Boutiques and Profit
}

\author{
NeLSON FLORES \\ University of Pennsylvania \\ nflores@upenn.edu \\ Ofelia García \\ The Graduate Center of the City University of New York \\ ogarcia@gc.cuny.edu
}

ABSTRACT

In this article we connect the institutionalization of bilingual education to a post-Civil Rights racial formation that located the root of educational inequalities in the psychological condition of people of color in ways that obscured the structural barriers confronting communities of color. Within this context, bilingual education was institutionalized with the goal of instilling cultural pride in Latinx students in ways that would remediate their perceived linguistic deficiencies. This left bilingual educators struggling to develop affirmative spaces for Latinx children within a context where these students continued to be devalued by the broader school and societal context. More recent years have witnessed the dismantling of these affirmative spaces and their replacement with two-way immersion programs that seek to cater to White middleclass families. While these programs have offered new spaces for the affirmation of the bilingualism of Latinx children, they do little to address the power hierarchies between the low-income Latinx communities and White middle-class communities that are being served by these programs. We end with a call to situate struggles for bilingual education within broader efforts to combat the racialization of Latinx and other minoritized communities.

\section{INTRODUCTION}

This is the story of bilingual education in the United States as told by two of its critical friends and advocates from two different generations. Ofelia was born in Cuba and arrived in New York City at the age of 11. Nelson was born in Philadelphia, of a Puerto Rican mother and an Ecuadorian father. In the United States, both were educated monolingually. Ofelia had no other choice because bilingual education was not offered at the time. Nelson was not given a choice because he was designated as fully English proficient when he arrived at school, and bilingual education programs offered in Philadelphia at the time were only available to students officially designated as "limited English proficient."

As students, we were not recognized for our bilingualism, which remained silent in school. For Ofelia, only the lunchroom remained a space for bilingualism, although monitors continuously reprimanded her for speaking 
Spanish with the other Latinas. Nelson did not hear Spanish in school at all until he was in 8th grade, when he was placed in the predominately White advanced class. The advanced class was the only class that was permitted to take Spanish rather than an extra block of English literacy, which the majority of the students of color in the school were required to take. As teachers, however, we were hired, in part, for our bilingual skills. As a first-time teacher, Ofelia was faced with a class of Puerto Rican children who didn't speak English and whom she was supposed to teach in English only. Nelson was hired as an English as second language teacher of Latinx students of different national origins and language proficiencies. But despite the official English context of the classroom - in Ofelia's case because the time for bilingual education had yet to come (it was 1970), and in Nelson's case because the time for bilingual education seemed to have passed (it was 2003) —our bilingualism was put to good use in educating the Latinx children we worked with.

In this article we combine our intergenerational experiences, as Latinxs who have dedicated our careers to the struggle for bilingual education, to explore the promises and perils of positioning bilingual education as a central focus of the political struggles of the Latinx community. Ofelia has direct experience with the early years of bilingual education that occurred within the context of the Civil Rights Movement and the War on Poverty. In the early years, bilingual education programs were often found in the basements of schools, with bilingual children segregated from the rest of the school community. Yet, despite this marginalized status within the schools, these bilingual programs opened the gates for Latinxs teachers, who had previously been systematically excluded from being hired, to enter the classroom as teachers of Latinx students (Reyes, 2006). Ofelia, and many other bilingual educators, took advantage of the affordances provided by their new positions within these bilingual basements to instill a sense of cultural pride in their Latinx students. "Estoy orgulloso de ser bilingüe" [I'm proud to be bilingual] was the mantra for many of these programs.

Nelson began his career in bilingual education in an extremely different sociopolitical context. He doesn't recall a time when bilingual education programs were promoted and protected by the federal government. Nor has he experienced the culturally relevant pedagogy that emerged in many of the racialized basements where earlier generations of bilingual education programs were regulated. Instead, at the beginning of his career, these racialized basements were undergoing a process of systematic dismantling as a result of conservative political attacks (Crawford, 2000). The bilingual education programs that continued to endure were a shell of their former selves as a result of the drying up of federal funding, massive political resistance, and the many challenges confronting the under-resourced schools that housed these programs, which were often in segregated and high-poverty neighborhoods that had been decimated by deindustrialization (Cahnmann, 1998). In their place arose "boutique programs," focused on "selling" bilingualism to powerful consumers. It was these boutique programs, often referred to as dual language or two-way immersion programs, that Nelson was taught to believe were the gold standard of bilingual education that bilingual education activists should strive for. 
In this way, the story of bilingual education in the United States in the post-Civil Rights era can be described as going from basements to boutiques. This move from basements to boutiques resonates with the tropes of pride and profit introduced by Duchêne and Heller (2013) in their discussion of language in late capitalism. These two ideologies — of pride and profit —operate dialectically and have been used differently to promote or restrict bilingual education from the mid-1960s to today. Based on our experiences as U.S. Latinx scholars and educators, we argue that neither pride nor profit are sufficient in improving the living conditions of Latinx communities. This is because both of these tropes position the locus of social change at the level of individuals in ways that obscure the structural barriers confronting Latinx children and communities. Pride suggests that improving the self-esteem of Latinx and other minoritized students will improve their academic achievement. Yet, a bilingual teacher seeking to do this must confront the larger school context that has often relegated these students to the basement, alongside broader societal messages that devalue and marginalize these students and their communities. In a similar vein, profit suggests that marketing bilingual education to powerful parents will increase the status of these programs. Yet, the stark inequalities that exist between the different stakeholders may lead to the exclusion of the minoritized students they were originally created to support (Valdez, Freire, \& Delavan, 2016). The limitations of both pride and profit stem from their lack of attention to the broader structural barriers confronting Latinx communities.

To be clear, we both believe that bilingual education continues to offer the possibility of challenging the marginalization of Latinx and other minoritized students. Yet, as we reflect on the history of the field in the post-Civil Rights era, we lament the fact that the lofty goals of original proponents of these programs within the Latinx community have not been fully achieved. The failure of bilingual education to meet these lofty goals should not be interpreted as a failure of bilingual education, but rather as a failure of U.S. society to address the underlying racialization processes that relegate Latinx and other minoritized communities to second-class status in U.S. society. That is, while bilingual educators have been able to create classrooms that affirm the bilingualism of their Latinx students in ways that instill cultural pride, they have been able to do little to challenge the structural barriers confronting their students in the broader society as reflected in their relegation to the basements of schools. Similarly, while dual language/twoway immersion programs may have moved bilingual education programs out of the basements, teachers in these programs can do little to challenge the vast inequities that exist between low-income Latinx students and their White middle-class counterparts in the broader society. In the next section, we connect this failure to confront the structural barriers confronting the Latinx and other minoritized communities to a broader post-Civil Rights discourse that framed the roots of racial inequalities as embedded within individuals as opposed to systematic exclusion. We then use this framing to reflect on the history of contemporary bilingual education in the United States. Our hope is that this critical analysis will serve to begin a conversation about the role of bilingual education advocacy work within efforts to dismantle the racial hierarchies of U.S. society. 
INSTITUTIONALIZING BILINGUAL EDUCATION IN THE POST-CIVIL RIGHTS ERA

Omi and Winant (1994) argued that the institutionalization of the demands of the Civil Rights Movement did not mark a break with the White supremacy of U.S. society but instead marked the beginning of a new racial formation that reconfigured White supremacy in ways that could accommodate the demands of the Civil Rights Movement while maintaining the racial status quo. Aggarwal (2016) pointed to the Brown v. Board of Education decision as providing the foundation for this post-Civil Rights racial formation. Aggarwal argued that the definition of harm used to inform the Brown decision was based on "a deficit framework of Black inferiority" that repositioned "political and economic questions as social problems" (Aggarwal, 2016, p. 132). In particular, Aggarwal pointed to the ways that the discourses surrounding the Brown decision were focused on the psychological damages caused by segregation on the internal psyche of Black children in ways that obscured the question of the legacy of racialized material inequalities that shaped their lives. From this perspective, problems of inequality in education are rooted in the deficiency of communities of color, and the solution becomes to fix these deficiencies. This post-Civil Rights racial formation also impacted the discussion related to the academic challenges confronting the Latinx community. A key difference is that, unlike the case with Black students, where segregation had historically been explicitly justified because of racial differences, segregation for the Latinx community was typically rationalized because of linguistic differences (Contreras \& Valverde, 1994).

At the dawn of the Civil Rights Movement, the situation of Latinx students was dire. A 1957 Texas report showed that the average Spanish-surnamed student spent 3 years in first grade and dropped out of school before reaching fifth grade (Browning \& McLemore, 1964). Likewise, a 1960 California study reported that over half of the Spanish-surnamed students had not gone beyond the eighth grade (Blanco, 1977). In 1960, of all Puerto Ricans 25 years of age and older in the United States, $87 \%$ had dropped out without graduating from high school (García, 2009).

It is within this context that calls for bilingual education emerged. On the one hand were proponents of bilingual education who framed bilingual education as part of a broader effort to dismantle White supremacist relations of power. These included radical Latinx political organizations such as the Young Lords and Brown Berets, who situated calls for bilingual education within a broader political platform that included radical visions of community control situated within the political and economic development of Latinx communities (Flores, 2016). This radical vision also included many other members of Latinx communities, for whom bilingual education was never simply a program to educate their children bilingually, but rather "a means to realize the promise of equal citizenship" (Del Valle, 1998, p. 194). On the other hand were proponents of bilingual education who framed bilingual education as part of efforts to improve the self-esteem of Latinx and other minoritized students. For example, in 1966 the powerful National Education 
Association (NEA) issued a report that stated that English-only practices in schooling led to damaged self-esteem, resentment, psychological withdrawal from school, and underachievement among Mexican Americans (NEA, 1966).

A year after the NEA report, Senator Ralph Yarborough from Texas introduced the Bilingual Education Act (BEA), which was intended to improve the educational experience of Spanish-speaking children. When he introduced the legislation in the U.S. Senate, he adopted a similar framing as the NEA report by suggesting that monolingual education policies "have caused great psychological harm to these [bilingual] children and contributed to their poor performance in school and high dropout rates" (cited in San Miguel, 2004). In short, similar to the Brown decision, the discourse surrounding the BEA framed the effects of racial inequalities as damaging to the internal psyche of Latinx children in ways that obscured questions related to the need for a redistribution of resources to compensate for centuries of White supremacist and monolingual policies. The result was that racial inequalities produced by a myriad of complex structural factors were reframed as linguistic problems with linguistic solutions (Flores, 2016). This framing is reflected in Lyndon B. Johnson's comments when he signed the BEA on January 2, 1968:

Thousands of children for Latin descent, young Indians, and others, will get a better start—a better chance-in school.... [W] e are now giving every child in America a better chance to touch his outermost limits - to reach the farthest edge of his talents and his dreams. We have begun a campaign to unlock the full potential of every boy and girl, regardless of his race or his region or his father's income. (Subcommittee on Education, 1968, p. 41)

Johnson's rhetoric was typical of the idealism of the 1960s, in its belief that reforms that sought to improve educational opportunities for communities of color would be able to undo the psychological damage caused by a legacy of racism and poverty.

The positioning of bilingual education as a panacea for the educational inequalities confronting Latinx was a double-edged sword. On the one hand, it was vital in supporting the work of pioneers in bilingual education. On the other hand, treating bilingual education as a panacea undermined the more radical demands of many bilingual education activists and distanced it from broader racial and economic equity struggles by refocusing it on technocratic issues related to the implementation of these programs (Grinberg \& Saavedra, 2000). As a result, the bilingual education programs that were institutionalized as part of the BEA were a far cry from the vision of bilingual education that many activists in these communities envisioned. In contrast to the vision of community-based bilingual-bicultural schools connected to broader political struggles for racial equity, the majority of the bilingual education programs that were organized as a result of the BEA were mostly transitional in nature (Del Valle, 1998). At best, these programs served as temporary "safe spaces" for students to develop cultural pride in ways that increased their self-esteem to prepare them to function in mainstream classrooms and the 
broader society. At worse, these programs perpetuated the continued racialization of Latinx and other minoritized communities by framing them as "the other" to the mainstream White norm. In this sense, the bilingual basement became a place where students could be proud of who they were, while simultaneously being oppressed for who they were.

Of course, it is the gift of hindsight that allows us to see the limits of the framing of the 1968 BEA and the ways that the construction of racialized basements inadvertently contributed to the post-Civil Rights racial formation that has allowed White supremacy to remain relatively intact. That is, we are not questioning the motives of the scholars and activists who fought for the passage of the BEA, nor are we suggesting that these individuals were racist. On the contrary, the BEA was passed with an explicitly antiracist goal of improving the academic achievement of Latinx and other minoritized students. Indeed, Ofelia was actively involved in fighting for the successful implementation of bilingual education programs in the early years of the implementation of BEA. Similarly, Nelson is indebted to the mentorship that he has received from Ofelia and other pioneers in the fight for bilingual education. What we are suggesting is that the last 50 years of bilingual education in U.S. schools have illustrated that the BEA and those who fought for it underestimated the continuing legacy of institutional racism that led to the construction of racialized basements: that contributed to the continued marginalization of Latinx children. It is to the construction of these racialized basements of bilingual education in the 1970s that we now turn.

\section{CONSTRUCTING RACIALIZED BASEMENTS OF BILINGUAL EDUCATION}

The construction of the racialized basements of bilingual education occurred as a product of two seemingly opposed sociopolitical processes. On the one hand were advocates for bilingual education who, appropriating discourses that stemmed back to the Brown decision, positioned bilingual education as combating racial inequalities by raising the self-esteem of Latinx and other minoritized communities. On the other hand were advocates for bilingual education who, adopting the assessment practices of the time, began to identify perceived linguistic deficiencies in Latinx and other minoritized students and saw bilingual education as the most viable option in remediating them. Though these two perspectives may seem to be opposed to one another, they were, in fact, co-constructed in many ways, such that bilingual education became framed as a way of instilling cultural pride in Latinx and other minoritized students in ways that would fix their linguistic deficiencies and improve their performance on standardized assessments.

Before looking closer at these two sociopolitical processes, it is important to situate the rise of racialized basements within the broader political context in which they emerged. These racialized basements emerged in perhaps the most politically hospitable context for bilingual education the country has witnessed. Decades of community mobilization had finally paid off with the federal government taking 
an active role in promoting bilingual education as a way of alleviating the civil unrest that had characterized the Civil Rights Movement. This hospitable context for bilingual education is reflected in a state-of-the-art study conducted by the Center for Applied Linguistics in the late 1970s:

\begin{abstract}
The concept of providing instruction in their own language to students who come to school speaking little or no English was given federal sanction in the 1968 Bilingual Education Act (Title VII, Elementary and Secondary Education Act)... . Momentum was increased by the landmark Lau v. Nichols decision in January 1974. The Supreme Court found that providing identical education programs for both English- and nonEnglish-speaking students did not constitute equal education opportunity and that special language instruction was necessary to allow non-English speakers real access to the content of the education services. Although not strictly mandated by the Lau decision, bilingual education has been seen by the Office of Civil Rights (DHEW) and subsequent court rulings as a major way of meeting the special needs of these students. (Parker, 1977, p. vii)
\end{abstract}

Ofelia vividly remembers this era of bilingual education when the federal government, through the Office of Civil Rights and the courts, offered explicit support for students receiving "instruction in their own language." In contrast, when Ofelia showed this description to Nelson for the first time, he found it alien to his own experiences as a bilingual educator. First of all, he was struck by the federal government supporting bilingual education — support that had essentially disappeared before he began his career in bilingual education. He was also struck by the explicit naming of the Bilingual Education Act, since the use of the term "bilingual" had also essentially disappeared from mainstream discourses before he began his career. He wondered what it was like to work in schools under the context of the Lau remedies that privileged bilingual education over English as a second language programs for meeting the needs of minoritized students (Castellanos, 1983). The discussion of "equal education opportunity" was also noteworthy in that Nelson has been much more accustomed to discussions of "gaps" rather than "opportunities." In short, the 1970s could be considered a time when there was the most federal support for bilingual education and the largest number of infrastructures for developing these programs.

In line with the psychological framing of the Brown decision, bilingual education was described by the U.S. government as developing "the children's self-esteem and a legitimate pride in both cultures." This point was reiterated by Blanco (1977), who described the state of the art of bilingual education for a compendium published by the Center for Applied Linguistics in 1977:

The consensus of writers in the field of bilingual education reveals that the primary thrust of bilingual education lies within the cognitive and affective domains, rather than the linguistic realm. The main purpose of bilingual education is not to teach language per se ... but to participate successfully in the education process. (pp. 4-5) 
In a similar vein, von Maltitz (1975) argued that the major goal of bilingualbicultural education was to lead students "to believe in themselves, in their basic worth as human beings, and in their native capacities." These early scholars of bilingual education were sure about two things: (a) positive self-esteem is a prerequisite for learning, and (b) participation in meaningful education produces learning. For these scholars, the purpose of bilingual education was to ensure that languageminoritized children, Chicanxs and Puerto Ricans in their majority, would engage cognitively and affectively as they participated in an education that extended their home and community socialization. This focus on instilling pride and improving the self-esteem of Latinx and other minoritized communities was discussed as part of the development of a new cultural democracy that stressed "the right of every American child to remain identified with his own home and community socialization experiences" (Castañeda, Herold, \& Ramírez, 1975, p. 10).

We in no way seek to minimize the important work done by scholars and activists to develop bilingual spaces that addressed students' affective concerns and sought to instill in them a sense of cultural pride. For the first time, the education of Latinx was in the hands of the community. Chicanx and Puerto Rican community members were hired as teachers. And those educators not only felt ownership of, and pride in, the education of their own children, but they also were deeply knowledgeable of the histories, language, and cultural practices of the youth. Families and communities were deeply engaged in schools, serving as teacher aides and extending the definition of school family. For the Chicanx communities of the Southwest and the Puerto Rican communities of the Northeast, there was pride in feeling that "Latinos, unidos, jamás serán vencidos." In short, the legitimation of bilingual education programs where the children's languages could be used was indeed welcomed by Latinx and other minoritized communities, as well as by progressive educators and scholars, in recognition that minoritized children had to be engaged in a meaningful and equitable education experience.

Yet, these affirmative spaces were not sufficient in dismantling the White supremacy that permeated U.S. institutions. An example of this continued legacy of White supremacy can be found in one of the BEA requirements for funding, which was that schools administer language proficiency assessments in both English and Spanish to determine eligibility for bilingual education programs. Many students performed poorly on these decontextualized assessments that did not align with the dynamic bilingualism of their lived experiences. As a result, many of these students were labeled "semilingual" or not fully proficient in either English or Spanish (Heath, 1984). One result of these assessment practices was that the bilingualism of Latinx and other minoritized children was reframed from a rallying cry connected to larger political struggles for community empowerment toward a deficit that needed to be fixed through pedagogical interventions (Flores, 2016).

In short, in the post-Civil Rights era, two major goals for bilingual education emerged. The first goal was for the programs to improve the self-esteem of Latinx and other minoritized students by instilling cultural pride. The second goal was for the programs to address the semilingualism of Latinx and other minoritized students by providing these students with a strong foundation in their first language 
that would then transfer to English (Cummins, 1979/2001). Neither of these goals addressed the underlying racialized positioning of Latinx and other minoritized communities within U.S. society. As a result, these programs were both literally and figuratively relegated to basements where bilingual educators were charged with seeking to balance the affirmation of student's identities with the realities of schooling and assessment practices designed to strip Latinx and other minoritized communities of their identities.

While divorcing bilingual education from broader political struggles and reframing them as compensatory programs for linguistically deficient students may have made them politically palatable in a context where politicians were trying to address civil unrest, it also made bilingual education programs vulnerable to political attacks.

The political attack on bilingual education occurred through the combined efforts of two different anti-bilingual education factions. The first faction was made up of critics who saw the promotion of bilingual education as a danger to national unity. In 1977, Noel Epstein, a Washington journalist, published an influential essay in which he argued that bilingual education was a policy of "affirmative ethnicity," and that the federal government should have no role in such a program.

The overriding question is whether the federal government is responsible for financing and promoting student attachments to their ethnic languages and cultures, jobs long left to families, religious groups, ethnic organizations, private schools, ethnic publications, and others. (Epstein, 1977, p. 20)

For Epstein and other critics of bilingual education, the racialized basements of bilingual education were not a product of the White supremacy of U.S. society that devalued the cultural and linguistic knowledge of Latinx students and relegated them to second-class status. Instead, these racialized basements indicated some type of ethnic conspiracy on the part of Latinx and other minoritized communities to undermine the unity of U.S. society. This would culminate in Senator S. I. Hayakawa of California and Dr. John Tanton teaming up to launch U.S. English in 1983, a movement that sought to make English the official language of the United States and to ban bilingual education in U.S. public schools (Crawford, 2000; García, 2009).

Opponents of bilingual education also appropriated the focus on assessment that was developed as a part of BEA requirements for funding in order to raise questions about the effectiveness of these programs. In 1978 the evaluation of bilingual education by the American Institutes for Research, known as the AIR Report, was published. The report concluded that bilingual education was not having a "consistent significant impact on student achievement in English language arts, math, or English reading" (cited in San Miguel, 2004, p. 44). This study accepted the premise that standardized assessments normed on monolingual populations and based on White middle-class cultural norms were valid indicators of the success, or lack thereof, of bilingual education programs serving low-income Latinx students. This same perspective was adopted by scholarly supporters of bilingual 
education who began to examine the impact of bilingual education programs on the standardized assessment scores of Latinx and other minoritized students (Collier \& Thomas, 2002; Rolstad, Mahoney, \& Glass, 2005; Willig, 1985). Though this research has been invaluable in supporting bilingual education programs, as with the AIR Report, these studies continue to privilege a particular locus of enunciation. By "locus of enunciation," we mean the political location within the structures of colonial power or knowledge from which a person speaks, which then shape what counts as knowledge and whose knowledge is made central to a particular narrative (Mignolo, 1995). The locus of enunciation inhabited by these research studies presupposes a detached scholar who can objectively determine the success or failure of bilingual education programs based on the objective assessment data.

Changing the locus of enunciation to that of Latinx children and families that participate in bilingual programs might offer counter-storytelling that starts from a different premise, has different priorities, and comes to different conclusions (Solorzano \& Yosso, 2001). As an example, researchers often worked from the assumption that students who remained in bilingual education programs for too long were "lagging behind," indicating that the program was not being successful at supporting the students. Yet, both of us have heard anecdotes about Latinx parents not wanting to have their children "mainstreamed" because they were convinced that the education they would receive in the English-only classrooms would be inferior to the education they were receiving in the bilingual program. Bilingual Latinx educators were seen by Latinx parents as having high expectations for these students. In contrast, Latinx parents often did not trust monolingual educators who were seen as "uncaring" and with whom they could not communicate. We have both also worked with bilingual educators who were convinced that the children were better off in their hands than in the hands of White educators who considered them inferior, inadequate, and unworthy of a meaningful education. These bilingual educators were convinced that Latinx students had a "better chance to learn" in bilingual programs (U.S. Commission on Civil Rights, 1975). We have both also met Latinx students in bilingual education programs who were happy to go to school because their teacher spoke their language and taught them a curriculum that reflected their lived experience and affirmed their bilingualism.

Some of our readers may object to these narratives as anecdotes that do not provide an objective description of the realities of these programs. We agree. However, these narratives are no more biased than representations of bilingual education based on culturally biased assessments normed on monolingual student populations. Suggesting that assessments that have historically labeled Latinx children as "semilingual" and continue to frame their bilingualism in deficit ways are objective measures of the capabilities of these students, in fact, demonstrates how deeply White supremacy permeates U.S. schools. It indicates that the cultural knowledge of Latinx and other minoritized students continues to be relegated to second-class status, which is a direct result of the racialized positioning of these communities in U.S. society. 
The assault on bilingual education and the locus of enunciation that dominated the debate led to the gradual dismantling of bilingual education programs as a result of the federal retrenchment from supporting them. In its original inception, the BEA funded demonstration projects where the students' languages other than English were used in instruction in "imaginative" programs (San Miguel, 2004). By 1974, there was a restriction of the "imaginative," as the reauthorized BEA bill defined bilingual education as:

Instruction given in, and study of, English and, to the extent necessary to allow a child to progress effectively through the educational system, the native language of the children of limited English-speaking ability. . . . Such instruction is given with appreciation for the cultural heritage of such children. (Public Law 93-380, August 21, 1974, Sec 702(a)(5), cited in San Miguel, 2004, p. 31).

This restriction of the imaginative was further strengthened with the election of Ronald Reagan, who made his views of bilingual education clear soon after entering office:

It is absolutely wrong and against American concepts to have a bilingual education program that is now openly, admittedly dedicating to preserving their [students who do not speak English] native language and never getting them adequate in English so they can go out into the job market and participate. (cited in García, 2009, p. 172)

The 1984 reauthorization of the BEA allowed, for the first time, the funding of English-only programs as long as they were no more than $4 \%$ of the total (Crawford, 2004; García, 2009).

In 1985, William J. Bennett, an opponent of bilingual education, was appointed to head the Department of Education. Under Bennett, new regulations were drafted that gave school districts flexibility to eliminate the use of languages other than English in educating students considered limited English proficient. In effect, bilingual education was decoupled from its civil rights obligations. Bennett was effective in dismantling the National Clearinghouse on Bilingual Education and in modifying the criteria for Title VII funds so that English-only approaches would also qualify for funding. And by 1988, when the BEA was again reauthorized, the quota for English-only programs eligible for funding was raised to 25\%. By 1994, the last time that Title VII was reauthorized, the quota for English-only programs was lifted, and for the first time, increased attention was given to two way immersion programs, programs that were to dominate the next stage of profit from bilingualism. By 2002, with the authorization of No Child Left Behind, Title VII (the BEA) was eliminated and replaced with Title III, now renamed the English Language Acquisition, Language Enhancement, and Academic Achievement Act. This was part of a larger effort to eliminate the "B-word" from federal legislation and federal agencies charged with supporting the educational needs of minoritized students (Crawford, 2004; Hornberger, 2006). It would appear that bilingual education as a racialized basement where bilingual teachers balanced instilling cultural 
pride in students with preparing them for success on assessments unrelated to their lived experiences was no longer a viable model for the education of Latinx and other minoritized students. This would lead from a move away from basements to boutiques, which began in the 1990s and continues today. It is to this new era of bilingual education that we now turn.

\section{FROM BASEMENTS TO BOUTIQUES}

In response to the assault on the racialized basements that had characterized bilingual education through the 1980s, a new model of bilingual education alternatively known as dual language education (DLE) or two-way immersion began to gain traction. Lindholm-Leary (2001) defined these programs:

DLE programs are similar in structure to immersion programs, but differ from the previously mentioned variations of immersion in terms of one very important factor: student composition. Unlike other forms of immersion, DLE includes native as well as non-native speakers of the target (non-English) language. In dual language programs, English-dominant and target-language-dominant students are purposefully integrated with the goals of developing bilingual skills, academic excellence, and positive crosscultural and personal competency attitudes for both groups of students. (p. 30)

Whereas, from its early U.S. beginnings, bilingual education had focused on more effective teaching of language-minoritized children, DLE programs were modeled after Canadian immersion programs and were geared toward the teaching of two languages by separating languages strictly and following an immersion pedagogy. The difference between teaching children bilingually and teaching two languages lies at the heart of the change that took place almost surreptitiously at this time. When teaching children bilingually is the goal, their dynamic bilingualism and cultural identities are made central to the curriculum in ways that are meant to instill cultural pride and improve their self-esteem. When teaching two languages is the goal, the dynamic bilingualism of Latinx and other minoritized communities becomes a barrier to instruction that seeks to police the boundaries between "English time" and "Spanish time" (García, 2009).

Connected to these new forms of language policing, DLE moves bilingual education away from the pride that characterized the racialized basements toward a commodified boutique where everybody could shop.

This converting of bilingual education from racialized basements to commodified boutiques connects to a broader shift in the post-Civil Rights racial formation away from a liberal multicultural focus on celebrating cultural pride to a neoliberal multicultural focus on commodifying diversity (Melamed, 2011). The shift to neoliberal multiculturalism shifted the discourse of social change away from increasing the self-esteem of students of color toward offering a range of choices on the educational marketplace that communities of color could choose from (Dumas, 2013). In the context of an assault on the racialized basements model of bilingual 
education, proponents of bilingual education, perhaps sensing that this was their only alternative, began to appropriate this neoliberal discourse to frame bilingual education as a choice among a menu of options that all families should have. As a result, bilingual education has shed not only its antidiscrimination and civil rights beginnings, but also its connection to Latinx and other minoritized communities. Instead, bilingual education has become a product with the consumers not necessarily being minoritized language users (Petrovic, 2005). The result is a constant tension between bilingual education as tending toward instilling pride in Latinx and other minoritized students and tending toward the sale of a product that is desired by White middle-class parents (Palmer, 2010). Because the availability of bilingual education is unevenly distributed across communities, DLE is mostly accessed by those who have the resources to profit from it (Morales \& Rao, 2015). In 1997, Guadalupe Valdés issued a cautionary note to that effect, warning that attention to the needs of White middle-class children instructed through Spanish would trump educating Latinx children bilingually. This criticism has only become more vocal in the last few years, as scholars decry the abandonment of equitable education for minoritized students and the increased focus on bilingualism for economic interests and global human capital (Cervantes-Soon, 2014; Flores, 2013; Valdez et al., 2016; Varghese \& Park, 2010).

In our continuing efforts to promote bilingual education, we have confronted the tensions between balancing the needs of Latinx and other minoritized communities and catering to the needs of White middle-class children. For example, Ofelia has witnessed that as bilingual education yielded its place to dual language education, the label dual language was extended to programs that once would have been considered developmental maintenance bilingual education programs. With the silencing of the word bilingual, committed educators started referring to these programs as one-way DLE. These programs serve Latinx and other minoritized children whose language performances fall along different points on the continua of biliteracy (Hornberger, 1989), not just those labeled as English learners. But ironically, and unfortunately, these one-way DLE programs gradually adopted the same language allocation policies and immersion practices of two-way DLE programs where languages were kept strictly separated and only standardized features of English and of the home language were legitimized. In a similar vein, Nelson has witnessed the ways in which two-way DLE programs are celebrated for "bringing parents back into public schools," whereas development maintenance bilingual education programs in the same district are at best ignored and at worst criticized for not teaching "those kids" English. Both of us have witnessed how the needs of White middle-class children and families trump the needs of low-income Latinx children and families because of fear that White middle-class families with more options may choose to leave the program. In this way, boutique two-way dual language programs, just like the racialized basements that they replaced, do not get to the root of the marginalization of Latinx children. The difference is that now Latinx children are treated as a commodity to boost the resumes of White middle-class children. 


\section{CONCLUSION}

Our committed intergenerational dialogue about bilingual education in the United States has exposed our differences as well as our unwavering commitment to Latinx students and their families. Ofelia sees the past in the racialized basements with nostalgia-ways of acting on some measure of self-determination, as Latinx educators were left alone to exert their Latinx pride and competence. At the same time, those racialized basements bred Latinx professionals who joined the teacher ranks. The Latinx community felt pride in being bilingual and profited economically from jobs that were needed in their communities. Nelson, younger and not having experienced this heyday of bilingual education, sees the racialized basements as places that did not change racial structures, either politically or educationally, and did not disrupt White supremacy. For him bilingual education has not changed the second-class status of the Latinx community especially now that bilingual education programs have become boutiques. In fact, it is the White English-speaking community that is profiting most from the boutique DLE programs.

We enter into this critique with tremendous pride in our positions as bilingual educators and delight in the work done by many bilingual educators, students, and families whom we meet daily. We also enter into this critique acknowledging that we have profited professionally from the bilingual education field, a field that has given us the passion and commitment to keep questioning its potential. The task for all of us is to acknowledge the pride and profit in continuing to fight for bilingual education, while refusing to accept that the only viable options for bilingual education are racialized basements or commodified boutiques. Instead, we must work to connect our advocacy for bilingual education with broader efforts to dismantle the racial hierarchies of U.S. society. Only then will these programs be able to thrive in the ways that advocates have envisioned since their inception in the political struggles of the 1960s.

\section{REFERENCES}

Aggarwal, U. (2016). The ideological architecture of whiteness as property in educational policy. Educational Policy, 30, 128-152.

Blanco, G. (1977). The education perspective. In Bilingual education: Current perspectives: Vol 4. Education (pp. 1-68). Washington, DC: Center for Applied Linguistics.

Browning, H., \& McLemore, S. D. (1964, January). The Spanish-surname population of Texas [Public affairs comment]. Austin: University of Texas.

Cahnmann, M. (1998). Over thirty years of language-in-education policy and planning: Potter Thomas bilingual school in Philadelphia. Bilingual Research Journal, 22, 65-81.

Castañeda, A., Herold, L. P., \& Ramírez, M. (1975). A new philosophy of education. Austin, TX: Dissemination and Assessment Center for Bilingual Education.

Castellanos, D. (1983). The best of two worlds: Bilingual-bicultural education in the U.S. Trenton, NJ: New Jersey Department of Education.

Cervantes-Soon, C. G. (2014). A critical look at dual language immersion in the new Latin@ diaspora. Bilingual Research Journal, 37(1), 64-82.

Collier, V., \& Thomas, W. (2002). The astounding effectiveness of dual language education for all. NABE Journal of Research and Practice, 2, 1-20.

Contreras, A., \& Valverde, L. (1994). The impact of Brown on the education of Latinos. Journal of Negro Education, 63, 470-481. 
Crawford, J. (2000). Anatomy of the English-only movement. In J. Crawford, At war with diversity: U.S. language policy in an age of anxiety (pp. 4-30). Clevedon, UK: Multilingual Matters.

Crawford, J. (2004). Educating English learners: Language diversity in the classroom (5th ed.). Los Angeles, CA: Bilingual Educational Services.

Cummins, J. (2001). Linguistic interdependence and the educational development of bilingual children. In C. Baker \& N. Hornberger (Eds.), An introductory reader to the writings of Jim Cummins (pp. 6395). Clevedon, UK: Multilingual Matters. (Original work published 1979).

Del Valle, S. 1998. Bilingual education for Puerto Ricans in New York City: From hope to compromise. Harvard Education Review, 68(2), 193-217.

Duchêne, A., \& Heller, M. (Eds.). (2013). Language in late capitalism: Pride and profit. New York, NY: Routledge.

Dumas, M. (2013). "Waiting for Superman" to save Black people: Racial representation and the official antiracism of neoliberal school reform. Discourse: Studies in the Cultural Politics of Education, 34, 531-547.

Epstein, N. (1977). Language, ethnicity and the schools: Policy alternatives for bilingual-bicultural education. Washington, DC: Institute for Educational Leadership.

Flores, N. (2013). The unexamined relationship between neoliberalism and plurilingualism: A cautionary tale. TESOL Quarterly, 47, 500-520.

Flores, N. (2016). A tale of two visions: Hegemonic whiteness and bilingual education. Educational Policy, 30, 13-38.

García, O. (2009). Bilingual education in the 21st century: A global perspective. Malden, MA: WileyBlackwell.

Grinberg, J., \& Saavedra, E. (2000). The constitution of bilingual/ESL education as a disciplinary practice. Review of Educational Research, 70, 419-441.

Heath, S. (1984). Linguistics and education. Annual Review of Anthropology, 13, 251-274.

Hornberger, N. (1989). Continua of biliteracy. Review of Educational Research, 59, 271-296.

Hornberger, N. (2006). Nichols to NCLB: Local and global perspectives on U.S. language education policy. In O. García, T. Skutnabb-Kangas, \& M. Torres-Guzman (Eds.), Imagining multilingual schools: Languages in education and glocalization (pp. 223-237). Clevedon, UK: Multilingual Matters.

Lindholm-Leary, K. J. (2001). Dual language education. Clevedon, UK: Multilingual Matters.

Melamed, J. (2011). Represent and destroy. Rationalizing violence in the new racial capitalism. Minneapolis: University of Minnesota Press.

Mignolo, W. (1995). The darker side of the renaissance: Literacy, territoriality and colonization. Ann Arbor: University of Michigan Press.

Morales, p. Z., \& Rao, A. B. (2015). How ideology and cultural capital shape the distribution of Illinois' bilingual education programs. Teachers College Record. Retrieved from https://www.tcrecord.org/content.asp?contentid=18139

National Education Association, Department of Rural Education. (1966). The invisible minority: Report of the NEA-Tucson survey on the teaching of Spanish to the Spanish-speaking. Washington, DC: Author.

Omi, M., \& Winant, H. (1994). Racial formation in the United States from the 1960s to the 1990s. New York, NY: Routledge.

Palmer, D. (2010). Race, power and equity in a multiethnic urban elementary school with a duallanguage "strand" program. Anthropology \& Education Quarterly, 41, 94-114.

Parker, L. L. (1977). Introduction. In Bilingual education: Current perspectives: Vol 4. Education ( $\mathrm{p}$. vii-ix). Washington, DC: Center for Applied Linguistics.

Petrovic, J. (2005). The conservative restoration and neoliberal defenses of bilingual education. Language Policy, 4, 395.

Reyes, L. (2006). The ASPIRA consent decree: A thirtieth anniversary retrospective of bilingual education in New York City. Harvard Educational Review, 76, 369-400.

Rolstad, K., Mahoney, K., \& Glass, G. V. (2005). The big picture: A meta-analysis of program effectiveness research on English language learners. Educational Policy, 19, 572-594.

San Miguel, G. (2004). Contested policy. The rise and fall of federal bilingual education in the United States 1960-2001. Denton: University of Texas Press.

Solorzano, D., \& Yosso, T. (2001). Critical race and LatCrit theory and method: Counter-storytelling. International Journal of Qualitative Studies in Education, 14, 491-495.

U.S. Commission on Civil Rights. (1975, May). A better chance to learn: Bilingual-bicultural education (Clearinghouse Publication No. 51).. Retrieved from ERIC database. (ED107417) 
Subcommittee on Education of the Committee on Labor and Public Welfare, 90th Congress 2d Session (1968, March). Committee print: Elementary and Secondary Education Act Amendments of 1967 with background materials and tables. Washington, DC: U.S. Government Printing Office.

Valdés, G. (1997). Dual-language immersion programs: A cautionary note concerning the education of language-minority students. Harvard Educational Review, 67, 391-429.

Varghese, M. M., \& Park, C. (2010). Going global: Can dual-language programs save bilingual education? Journal of Latinos and Education, 9(1), 72-80.

Valdez, V., Freire, J., \& Delavan, M. (2016). The gentrification of dual language education. The Urban Review, 48, 601-627.

von Maltitz, F. W. (1975). Living and learning in two languages: Bilingual-bicultural education in the United States. New York, NY: McGraw-Hill.

Willig, A. C. (1985). A meta-analysis of selected studies on the effectiveness of bilingual education. Review of Educational Research, 55, 269-317. 